\title{
Hand hygiene myths
}

\author{
AJ Stewardson ${ }^{1 *}$, B Allegranzi ${ }^{2}$, H Sax ${ }^{1}$, C Kilpatrick ${ }^{2}$, D Pittet ${ }^{1,2}$ \\ From International Conference on Prevention \& Infection Control (ICPIC 2011) \\ Geneva, Switzerland. 29 June - 2 July 2011
}

\section{Introduction / objectives}

Professionals promoting hand hygiene $(\mathrm{HH})$ with multimodal strategies featuring the introduction of alcoholbased handrub (ABHR) are confronted by a common set of impeding opinions regarding the indications, safety and efficacy of ABHR. Some of these could be referred to as $\mathrm{HH}$ myths.

\section{Methods}

We undertook a review of the literature to assess the currently available evidence regarding five common barriers to the successful implementation ABHR: 1) poor $\mathrm{HH}$ before patient contact; 2) the risk of systemic absorption of alcohol; 3) adverse dermatologic effects; 4) risk of Clostridium difficile disease; and 5) ABHR as a fire hazard.

\section{Results}

Hand hygiene compliance is usually better after patient contact than before, despite a lack of evidence to suggest this is an effective means to prevent transmission of pathogens. Blood levels of ethanol and acetone after even supra-normal exposure are undetectable or insignificant. Appropriately formulated ABHR products are less likely to result in dermatitis than washing with soap and water. Appropriate implementation of hand hygiene guidelines does not result in Clostridium difficile infection incidence. Fire events related to ABHR are extremely rare and almost exclusively associated with inappropriate use.

\section{Conclusion}

Like any medication, ABHRs do have potential adverse effects, but these can be minimised by appropriate usage. Rare or even mythic complications should be weighed realistically against the potential of ABHR to prevent countless healthcare-associated infections each year.

${ }^{1}$ University of Geneva Hospitals, Geneva, Switzerland

Full list of author information is available at the end of the article

\section{Disclosure of interest}

None declared.

Author details

${ }^{1}$ University of Geneva Hospitals, Geneva, Switzerland. ${ }^{2}$ WHO, Geneva, Switzerland.

Published: 29 June 2011

doi:10.1186/1753-6561-5-S6-P101

Cite this article as: Stewardson et al:: Hand hygiene myths. $B M C$

Proceedings 2011 5(Suppl 6):P101.
Submit your next manuscript to BioMed Central and take full advantage of:

- Convenient online submission

- Thorough peer review

- No space constraints or color figure charges

- Immediate publication on acceptance

- Inclusion in PubMed, CAS, Scopus and Google Scholar

- Research which is freely available for redistribution

\section{() Biomed Central}

\section{Ciomed Central}

